\title{
Diffusion of calcium hydroxide through dentinal tubules of retreated root canals: An in vitro study
}

\author{
Mohammed Mustafa ${ }^{1}$, Wafa Hassan Alaajam², Ahmed Abdul Azeim², Najla Aedh Alfayi ${ }^{3}$, \\ Rahaif Misfer Alqobty ${ }^{3}$, Shahad Alghannam ${ }^{4}$
}

Correspondence: Dr. Mohammed Mustafa

Email:ma.mustafa@psau.edu.sa

\begin{abstract}
'Department of Conservative Dental Sciences, Division of Endodontics, College of Dentistry, Prince Sattam bin Abdulaziz University, AlKharj, Saudi Arabia,

${ }^{2}$ Department of Conservative Dental Sciences, Division of Endodontics, College of Dentistry, King Khalid University, Abha, Saudi Arabia,

${ }^{3}$ General Dentist, Abha, Saudi Arabia,

${ }^{4}$ General Dentist,College of Dentistry and Hospital, Prince

Sattam bin Abdulaziz University, AlKharj, Saudi Arabia
\end{abstract}

\section{ABSTRACT}

Objective: Studies about the dispersion of hydroxyl ions through dentin of endodontically retreated teeth are scarce. The present study aims at examining the diffusion of calcium hydroxide in vitro by recording the $\mathrm{pH}$ changes of retreated root canal using two types of calcium hydroxide preparations. Materials and Methods: A total of 45 recently extracted single-rooted mandibular first premolars were collected and cleaned from calculus and remains of periodontal tissue. The teeth so collected were stored in thymol $10 \%$ solution till use. During collection, teeth with cracks, open apices, and restorations were excluded. Root canal preparations were performed using Protaper rotary system files, till $\mathrm{HF} 3$ file. All canals were obturated using cold lateral condensation and zinc oxide-based sealer. After 7 days, all gutta-percha were removed and the canals were irrigated with normal saline. The teeth were then randomly distributed into three groups. Canals in Group I were kept empty without any dressing to serve as a negative control group, Canals in Group II were filled with a freshly prepared mixture of calcium hydroxide powder with normal saline solution, and Group III was filled with Metapex. Periodically, the calcium hydroxide material was removed and the $\mathrm{pH}$ was measured using $\mathrm{pH}$ meter at 7 , 10, 14, and 30 days. Results: The $\mathrm{pH}$ values of Group II and III ranged between 9.2 and 11.2. This was found to be highly significant against the negative control group. After 7 and 10 days, freshly mixed $\mathrm{Ca}(\mathrm{OH})_{2}$ showed the higher $\mathrm{pH}$ than the creamy Metapex, and statistically the difference was highly significant after 10 days $(P<0.001)$. After 14 days, Metapex group $\mathrm{pH}$ was higher than freshly mixed $\mathrm{Ca}(\mathrm{OH})_{2}$, but it was not statistically significant as they reached nearly the same $\mathrm{pH}$ after 30 days $(P>0.05)$. Conclusion: $\mathrm{All} \mathrm{Ca}(\mathrm{OH})_{2}$ preparations had high $\mathrm{pH}$ around the roots after 7 and 10 days. Metapex continued to have higher $\mathrm{pH}$ after 14 days.

Key words: Calcium hydroxide, Dentinal tubules, Metapex, Retreated root canals

\section{INTRODUCTION}

Root canal therapy eradicates bacteria from infected root canals and prevents reinfection. Inappropriate mechanical debridement or persistence of bacteria in the root canal structure due to poorly performed

\begin{tabular}{|l|l|}
\hline \multicolumn{2}{|c|}{ Access this article online } \\
\hline Quick Response Code: \\
\hline
\end{tabular}

root canal therapy may lead to failure. ${ }^{[1]}$ Failure of root canal treatment can be managed by nonsurgical retreatment. Calcium hydroxide has been widely

This is an open access journal, and articles are distributed under the terms of the Creative Commons Attribution-NonCommercial-ShareAlike 4.0 License, which allows others to remix, tweak, and build upon the work non-commercially, as long as appropriate credit is given and the new creations are licensed under the identical terms.

For reprints contact: reprints@medknow.com

How to cite this article: Mustafa M, Alaajam WH, Azeim AA, Alfayi NA, Alqobty RM, Alghannam S. Diffusion of calcium hydroxide through dentinal tubules of retreated root canals: An in vitro study. Eur J Dent 2018;12:386-92.

DOI: 10.4103/ejd.ejd_77_18 
used in endodontics as an intracanal medicament because of its bactericidal activities, especially in retreatment cases. This has also been suggested for use as intracanal medicament because of its antiresorptive and tissue dissolving properties. ${ }^{[2]}$

It was in 1920 that Herman introduced calcium hydroxide $\left(\mathrm{Ca}(\mathrm{OH})_{2}\right)$ as a pulp-capping agent, to the field of endodontics. ${ }^{[3]} \mathrm{Ca}(\mathrm{OH})_{2}$ is a white odorless powder having a molecular weight of 74.08 . It has less solubility in water (about $1.2 \mathrm{~g} / \mathrm{L}$ at $25^{\circ} \mathrm{C}$ ). Although it does not have property of bonding to dentin, it has antibacterial property. ${ }^{[4]} \mathrm{Ca}(\mathrm{OH})_{2}$ exhibits lethal effects on bacteria as a result of damage to DNA, protein denaturation, and the damage caused to cytoplasmic membranes. On common endodontic pathogens, it is found to exhibit an extensive range of antimicrobial activities. Further, it maintains high $\mathrm{pH}$ after setting, as the material dissolves readily in aqueous solution and liberating hydroxyl ions. This high $\mathrm{pH}$ delivers an incentive for tooth to repair himself in nonexistence of bacterial infection. ${ }^{[5]}$

$\mathrm{Ca}(\mathrm{OH})_{2}$ has low solubility in tissue fluids, even when there is direct contact with vital tissues. It has an alkaline $\mathrm{pH}$ (about 12.5-12.8), which is chemically categorized as a strong base. The material has the ability to quickly separate into hydroxyl ions and calcium ions and maintain a high $\mathrm{pH}$, and lead to bactericidal effects in the root canal system. ${ }^{[6,7]}$

For $\mathrm{Ca}(\mathrm{OH})_{2}$ to perform efficiently as an intracanal medicament, hydroxyl ions must diffuse through dentine. It is expected that this would occur in a similar manner with water because dispersion through dentine is principally determined by molecular weight. Various studies have attempted to identify the quantity of diffusion of hydroxyl ions into the dentin using a diversity of experimental methods, comprising $\mathrm{pH}$ indicating solutions or papers, $\mathrm{pH}$ values of the surrounding medium, and $\mathrm{pH}$ measurement of ground dentin. ${ }^{[5-7]}$

$\mathrm{Ca}(\mathrm{OH})_{2}$ controls infection and decrease the incidence of unfavorable symptoms. It is also used in various clinical situations as an intracanal medicament, been shown to decrease the pathogens associated with pulp necrosis, and limit root resorption and promote the repair of periapical tissues. ${ }^{[8-10]}$

Kazemipoor et al, ${ }^{[11]}$ have stated that the difficulties which are more challenging in the retreated canals are the openings of dentinal tubules which may be blocked with residual sealer and gutta-percha. This phenomenon can have an influence on the diffusion and penetration of hydroxyl ions into the dentinal tubules.

Pashley and Livingston had suggested that hydrogen and hydroxyl ions like water should diffuse readily through dentine since permeability was in general inversely related to molecular size, and in this study where molecular charge was examined as a variable it did not appear to influence the rate of diffusion. ${ }^{[12]}$

There are only limited studies that have examined the diffusion dynamic of hydroxyl ions through dentinal tubules of retreated teeth. The present study was done to examine the diffusion of $\mathrm{Ca}(\mathrm{OH})_{2}$ through dentinal tubules of retreated root canals using two different types of $\mathrm{Ca}(\mathrm{OH})_{2}$ preparations.

\section{MATERIALS AND METHODS}

A total of 45 extracted single-rooted mandibular first premolars were taken for the study. The teeth were cleaned from calculus and any remains of periodontal tissue and kept in a thymol 10\% solution till use.

\section{Inclusion criteria}

The inclusion criteria were as follows:

1. The premolars of patients aged between 16 and 20 years old, with single canal extracted for orthodontic purpose were collected for this study

2. In the selected tooth, the presence of single root canal was verified using two digital radiographs in both buccolingual and mesiodistal directions.

\section{Exclusion criteria}

1. Teeth with restorations, cracks, and open apices were excluded from the study.

Ethical approval was obtained from the Department of Conservative Dental Sciences, College of Dentistry, Prince Sattam bin Abdulaziz University, before the study. All the teeth used in this study were cleaned using running tap water and then stored in normal saline. The crowns were transversally sectioned with a diamond-cutting disc at the cementoenamel junction level.

The length of the root canals was recorded at $1 \mathrm{~mm}$ short of the main apical foramen and was standardized to nearly the same lengths $(13 \pm 1 \mathrm{~mm})$ for all the sample teeth as shown in Figure 1. Glyde (DENTSPLY, Maillefer) has been used as a lubricant. Root canals were prepared using Protaper (DENTSPLY, Tulsa) rotary system files 
using an electric motor (X-Smart; DENTSPLY, Maillefer), till \#F3 file. Irrigation during cleansing and shaping was accomplished using distilled water. After instrumentation, a \#30 file was introduced up to the total length of the root canal for apical cleaning, and the root canal was then filled with a solution of ethylenediaminetetraacetic (EDTA) (ULTRADENT, IndiSpense) for $3 \mathrm{~min}$. The root canals were then cleansed with normal saline solution and then absorbent paper points were used for drying. Then, all canals were obturated using cold lateral condensation technique. Each tooth was placed in a container with unbuffered isotonic saline soaked in cotton wool, which allows the sealer to set, kept in an oven at $37^{\circ} \mathrm{C}$, with $100 \%$ humidity for 7 days. After that, the gutta-percha was removed from the canals using chloroform and Protaper Universal Retreatment file \# D3 (Protaper® Universal Retreatment, DENTSPLY), along with the removal of certain amount of sound dentin. The dentinal thickness in apical, middle, and coronal third was measured using digital radiograph in mesiodistal and buccolingual direction as shown in Figure 1. Then, the selected teeth were randomly distributed into three groups, each group comprising 15 teeth:

- Group I: 15 root canals will not be filled with anything to be used as control group, as shown in Figure 2

- Group II: 15 root canals will be filled with a fresh mixture of calcium hydroxide powder (Pulpdent Corporation, USA) and distilled water solution, as shown in Figure 3

- Group III: 15 root canals will be filled with oily readymade calcium hydroxide Metapex (Meta Biomed, Korea), as shown in Figure 4.

The coronal access cavities and the apical openings were sealed with amalgam restoration. Each specimen was kept in small vial with $30 \mathrm{ml}$ of deionized water kept in an oven at $37^{\circ} \mathrm{C}$, with $100 \%$ humidity; to be used for $\mathrm{pH}$ measurements after 7, 10, 14, and 30 days using $\mathrm{pH}$ meter.

When measuring the $\mathrm{pH}$, the tooth was removed from the vial and rinsed with saline. At the end of each stage, the teeth were placed back in the same vial with freshly placed cotton saturated with saline.

\section{RESULTS}

The average baseline $\mathrm{pH}$ in control group was similar ( $\mathrm{pH}$ 6.9-7.4). The $\mathrm{pH}$ values of both $\mathrm{Ca}(\mathrm{OH})_{2}$ was between 9.2 and 11.2 when measured in all the

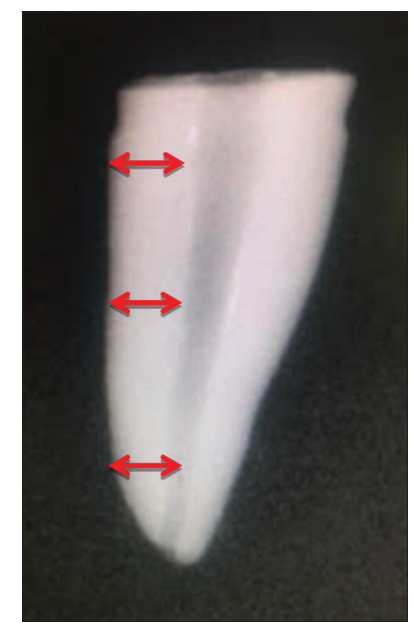

Figure 1: Peri-radicular radiograph showing the dentinal wall width of a sample

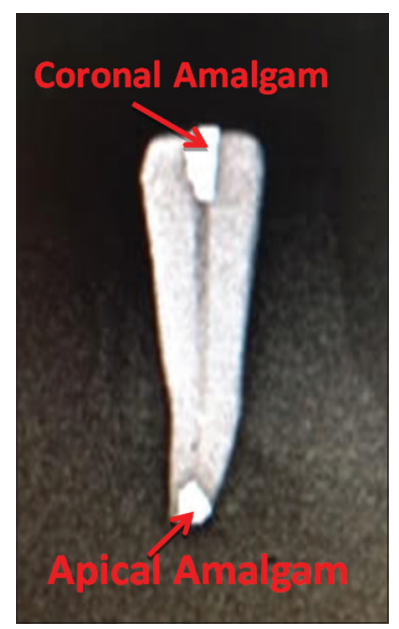

Figure 2: Peri-radicular radiograph showing a sample from control group

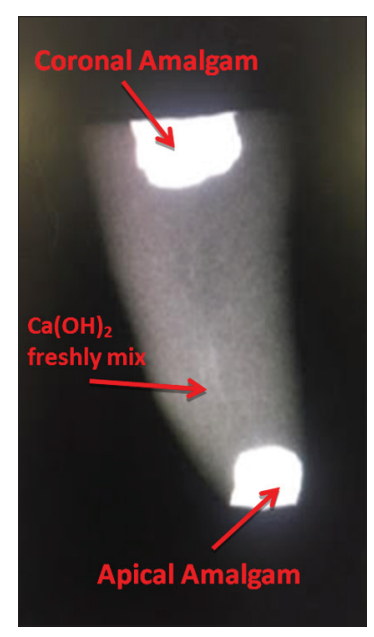

Figure 3: Peri-radicular radiograph showing freshly mixed $\mathrm{Ca}(\mathrm{OH})_{2}$ inside the canal with the coronal and apical amalgam seals of a sample from Group II

four periods which were highly significant than the negative control group. 
Table 1 shows the mean of $\mathrm{pH}$ readings of the control group after $7,10,14$, and 30 days. The $\mathrm{pH}$ value dropped after 14 and 30 days, while no significant change in the $\mathrm{pH}$ after 7 and 10 days.

Table 2 shows mean of $\mathrm{pH}$ readings of freshly mixed calcium hydroxide group after 7, 10, 14, and 30 days. The $\mathrm{pH}$ reading was shown an increase after 10 and 14 days, while no significant increase in $\mathrm{pH}$ after 30 days.

Table 3 shows the mean of $\mathrm{pH}$ readings of Metapex group after 7, 10, 14, and 30 days and no significant change in the reading in the $\mathrm{pH}$ was noticed.

After 7 and 10 days, freshly mixed $\mathrm{Ca}(\mathrm{OH})_{2}$ showed the higher $\mathrm{pH}$ than the creamy Metapex, and statistically, the difference was highly significant after 10 days $(P<0.001)$.

After 14 days, Metapex group $\mathrm{pH}$ was higher than freshly mixed $\mathrm{Ca}(\mathrm{OH})_{2}$, but it was not statistically significant, they reached the same $\mathrm{pH}$ after 30 days $(P>0.05)$. Descriptive statistics using one-way ANOVA test was used to compare the $\mathrm{pH}$ values for different types of $\mathrm{Ca}(\mathrm{OH})_{2}$ at different time periods and multiple comparisons post hoc test was used in this study to get the results [Table 4].

Graph 1 presents the comparison of the changes in the $\mathrm{pH}$ reading of all the three groups after 7,10 , 14 , and 30 days. The control group does not show any significant change in the $\mathrm{pH}$ reading, while the Group III has shown changes in the $\mathrm{pH}$ reading, but it was less as compared to the Group II [Graph 1].

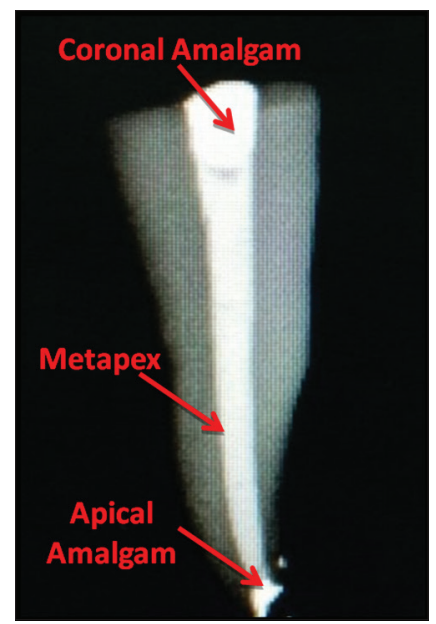

Figure 4: Peri-radicular radiograph showing Metapex inside the canal with the coronal and apical amalgam seals of a sample from Group III

\section{DISCUSSION}

The desired beneficial effect of $\mathrm{Ca}(\mathrm{OH})_{2}$ is dependent on its separation into hydroxyl ion and calcium ion, and their diffusion through the dentinal tubules and the apical foramen. When the hydroxyl ions diffused, the $\mathrm{pH}$ will be raised causing destruction of bacteria, reduction of osteoclastic activity, inactivation of bacterial enzymes, and activation of alkaline phosphatase which is involved in mineralization. ${ }^{[10]}$ Diffusion of $\mathrm{Ca}(\mathrm{OH})_{2}$ through dentinal tubules has been studied in the recent years. ${ }^{[13,14]}$

According to Ba-Hattab et al, ${ }^{[15]}$ The hydroxyl ions release in an aqueous environment is necessary for antimicrobial activity of calcium hydroxide. Hydroxyl ions react intensively with biomolecules because of their free radicals. As this reactivity is unspecified, the free radicals most likely gathered at the sites of generation.

For the medications to show complete efficacy, they have to be in contact with the dentin for certain period and also be able to enter the dentinal tubules. Therefore, the intracanal medicaments' proper wetting with the radicular dentine and contact angle between the hard tissue and the paste should be considered..$^{[16]}$ According to Kontakiotis et al, ${ }^{[17]}$ wetting of aqueous liquid means that, an edge contact is being molded between a liquid and a solid with a concurrent exclusion of air. The propensity of a liquid to wet a solid surface is conveyed with the development of a contact angle. Principally, the lower the angle, the faster the liquid medium will wet on the tooth surface, and a contact angle of $<90^{\circ}$ designates good wetting properties.

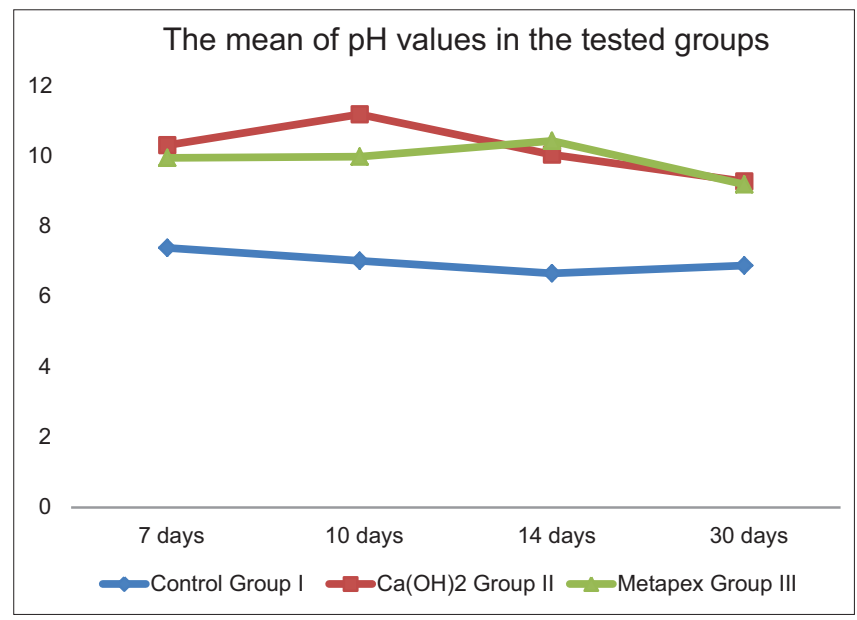

Graph 1: The mean of $\mathrm{pH}$ values of the three test groups (Group I = control group, Group II = calcium hydroxide, and Group III = Metapex in the four tested periods (7 days, 10 days, 14 days, and 30 days) 


\begin{tabular}{|c|c|c|c|c|}
\hline \multicolumn{5}{|c|}{$\mathrm{pH}$ readings of group I } \\
\hline \multirow{2}{*}{$\begin{array}{l}\text { Sample } \\
\text { no. }\end{array}$} & \multicolumn{4}{|c|}{ Mean } \\
\hline & $\begin{array}{c}\text { After } \\
7 \text { days }\end{array}$ & $\begin{array}{c}\text { After } \\
10 \text { days }\end{array}$ & $\begin{array}{c}\text { After } \\
14 \text { days }\end{array}$ & $\begin{array}{c}\text { After } \\
30 \text { days }\end{array}$ \\
\hline 1 & 7.336 & 8.236 & 6.808 & 6.928 \\
\hline 2 & 7.420 & 8.034 & 6.484 & 6.798 \\
\hline 3 & 7.296 & 7.986 & 7.004 & 6.726 \\
\hline 4 & 7.420 & 8.236 & 6.388 & 6.720 \\
\hline 5 & 7.570 & 8.002 & 6.688 & 7.770 \\
\hline 6 & 7.276 & 7.950 & 6.528 & 6.608 \\
\hline 7 & 7.362 & 7.762 & 6.802 & 6.716 \\
\hline 8 & 7.360 & 8.034 & 6.484 & 6.798 \\
\hline 9 & 7.296 & 7.986 & 7.004 & 6.726 \\
\hline 10 & 7.420 & 8.236 & 6.388 & 6.720 \\
\hline 11 & 7.570 & 8.002 & 6.688 & 7.770 \\
\hline 12 & 7.276 & 7.950 & 6.528 & 6.608 \\
\hline 13 & 7.362 & 7.762 & 6.802 & 6.716 \\
\hline 14 & 7.296 & 8.236 & 6.808 & 6.798 \\
\hline 15 & 7.420 & 8.034 & 6.484 & 6.726 \\
\hline
\end{tabular}

\begin{tabular}{lcccc}
$\begin{array}{l}\text { Table 3: Mean of pH readings of Group III (Metapex } \\
\text { Group) }\end{array}$ & \multicolumn{5}{c}{ M } \\
\hline \multicolumn{5}{c}{ pH readings of group III } \\
\hline Sample & \multicolumn{4}{c}{ Mean } \\
no. & After & After & After & After \\
& $\mathbf{7}$ days & $\mathbf{1 0}$ days & $\mathbf{1 4}$ days & $\mathbf{3 0}$ days \\
\hline 31 & 8.902 & 7.166 & 9.144 & 8.192 \\
32 & 8.180 & 8.594 & 8.194 & 10.160 \\
33 & 11.098 & 10.484 & 10.346 & 9.308 \\
34 & 10.184 & 10.270 & 10.832 & 9.258 \\
35 & 10.260 & 8.882 & 10.772 & 9.374 \\
36 & 10.130 & 10.648 & 11.356 & 9.722 \\
37 & 9.890 & 10.154 & 11.124 & 9.310 \\
38 & 11.008 & 10.444 & 11.218 & 9.380 \\
39 & 10.962 & 10.062 & 10.772 & 9.186 \\
40 & 10.126 & 10.256 & 10.440 & 9.560 \\
41 & 9.198 & 8.202 & 10.356 & 8.038 \\
42 & 8.958 & 7.212 & 9.458 & 9.984 \\
43 & 10.290 & 10.192 & 10.268 & 8.548 \\
44 & 9.862 & 9.722 & 11.156 & 8.922 \\
45 & 10.446 & 9.686 & 11.308 & 9.186 \\
\hline
\end{tabular}

Madarati et al, ${ }^{[18]}$ conducted a study, in which participants were aware that the main function of intracanal medicaments is disinfection of the root canal system, where $\mathrm{Ca}(\mathrm{OH})_{2}$ was used as an intracanal medicament in necrotic pulp cases.

The study conducted by Rizvi et al, ${ }^{[19]}$ states that MTAD is effective in the eradication of Enterococcus faecalis, around neutral $\mathrm{pH}$, the effective inhibition of E. faecalis is better than the other root canal irrigants investigated in this study such as sodium hypochlorite, EDTA, and chlorhexidine.

\begin{tabular}{|c|c|c|c|c|}
\hline \multicolumn{5}{|c|}{$\mathrm{pH}$ readings of group II } \\
\hline \multirow{2}{*}{$\begin{array}{l}\text { Sample } \\
\text { no. }\end{array}$} & \multicolumn{4}{|c|}{ Mean } \\
\hline & $\begin{array}{c}\text { After } \\
7 \text { days }\end{array}$ & $\begin{array}{c}\text { After } \\
10 \text { days }\end{array}$ & $\begin{array}{c}\text { After } \\
14 \text { days }\end{array}$ & $\begin{array}{c}\text { After } \\
30 \text { days }\end{array}$ \\
\hline 16 & 10.555 & 11.764 & 9.866 & 8.250 \\
\hline 17 & 10.320 & 11.250 & 10.932 & 9.678 \\
\hline 18 & 11.086 & 11.778 & 10.956 & 8.452 \\
\hline 19 & 10.450 & 11.778 & 10.000 & 8.786 \\
\hline 20 & 10.088 & 11.778 & 11.072 & 10.550 \\
\hline 21 & 10.498 & 11.246 & 10.702 & 9.170 \\
\hline 22 & 10.650 & 11.720 & 10.028 & 10.204 \\
\hline 23 & 9.854 & 10.822 & 10.402 & 9.558 \\
\hline 24 & 9.532 & 10.548 & 9.724 & 8.994 \\
\hline 25 & 10.436 & 11.550 & 10.802 & 8.878 \\
\hline 26 & 9.458 & 9.844 & 7.826 & 7.646 \\
\hline 27 & 10.766 & 11.674 & 10.178 & 8.862 \\
\hline 28 & 8.356 & 9.200 & 7.994 & 9.156 \\
\hline 29 & 11.280 & 11.222 & 10.822 & 10.896 \\
\hline 30 & 11.594 & 11.918 & 9.536 & 8.124 \\
\hline
\end{tabular}

Yücel et al, ${ }^{[20]}$ stated that for proper wetting of the canal wall, $\mathrm{Ca}(\mathrm{OH})_{2}$ powder has been used as a mixture for root canal dressing and can be mixed with vehicles such as olive oil, glycerin, propylene glycol, iodoform plus saline solution, camphorated parachlorophenol plus glycerin, camphorated parachlorophenol, methylcellulose, metacresylacetate, saline, distilled water, anesthetic solutions, Ringer's solution, and camphorated monochlorophenol cresatin.

Besides permitting diffusion of the $\mathrm{Ca}(\mathrm{OH})_{2}$, the vehicle can enhance the antimicrobial capacity of the paste. ${ }^{[21]}$ According to Gomes et al, ${ }^{[22]}$ chlorhexidine can be used as a vehicle for attempting an increase in the antimicrobial property to be effective against aerobic and facultative anaerobic microorganisms, Gram-positive and Gram-negative microorganisms, yeasts, and viruses.

Only a few studies have evaluated the dissolution capacity of $\mathrm{Ca}(\mathrm{OH})_{2}$ preparations in retreated cases. During the root canal retreatment procedure, the dentinal tubules openings may be obstructed with gutta-percha and the remaining sealer. This can impact on the penetration and diffusion of hydroxyl ions through dentinal tubules. Hence, we intended to remove sound dentin during removal of the gutta-percha. The permeability of dentin is directed mostly by dentin tubule anatomy, diameter, density, and length as well as features of the solute such as charge and size. Dentin is a substrate, whereas calcium hydroxide is a material. The size of the 
Mustafa, et al:: Diffusion of calcium hydroxide through dentinal tubules of retreated root canals

\begin{tabular}{|c|c|c|c|c|c|c|c|}
\hline \multirow[t]{2}{*}{$n$} & \multicolumn{3}{|c|}{ Descriptive (one way) } & \multicolumn{4}{|c|}{ Multiple comparisons (post hoc test) } \\
\hline & $\begin{array}{c}\text { Group I (Control) } \\
\text { Mean } \pm \text { SD }\end{array}$ & $\begin{array}{c}\text { Group II Ca }(\mathrm{OH})_{2} \\
\text { Mean } \pm S D\end{array}$ & $\begin{array}{c}\text { Group III (Metapex) } \\
\text { Mean } \pm S D\end{array}$ & $P$ & $\mathrm{PI}$ and II & PI and III & PII and III \\
\hline Day 7 & $7.398 \pm 0.108$ & $10.328 \pm 0.804$ & $9.966 \pm 0.838$ & 0.000 & 0.000 & 0.000 & 0.193 \\
\hline Day 10 & $7.029 \pm 0.166$ & $11.206 \pm 0.796$ & $10.00 \pm 1.171$ & 0.000 & 0.000 & 0.000 & 0.000 \\
\hline Day 14 & $6.672 \pm 0.217$ & $10.056 \pm 0.998$ & $10.450 \pm 0.898$ & 0.000 & 0.000 & 0.000 & 0.222 \\
\hline Day 30 & $6.895 \pm 0.398$ & $9.295 \pm 0.906$ & $9.209 \pm 0.591$ & 0.000 & 0.000 & 0.000 & 0.815 \\
\hline
\end{tabular}

dentin tubules correlates with the size of the $\mathrm{Ca}(\mathrm{OH})_{2}$ particles. ${ }^{[23,24]}$

In the present study, in one group, we used $\mathrm{Ca}(\mathrm{OH})_{2}$ powder mixed with distilled water; and in the other group, we used oily Metapex composed of $\mathrm{Ca}(\mathrm{OH})_{2}$, iodoform, and silicon oil to fill the canals of retreated roots. To simulate the clinical condition, samples were kept in incubator at $37^{\circ} \mathrm{C}$ during the testing periods. According to the condition of our study, the normal baseline $\mathrm{pH}$ in negative control group was similar ( $\mathrm{pH}$ 6.9-7.4). Both $\mathrm{Ca}(\mathrm{OH})_{2}$ types showed $\mathrm{pH}$ values between 9.2 and 11.2, when measured in all the four periods which were highly significant than the negative control group and these are consistent with most studies. ${ }^{[25-27]}$

After 7 and 10 days, freshly mixed $\mathrm{Ca}(\mathrm{OH})_{2}$ showed higher $\mathrm{pH}$ than the creamy Metapex. Statistically, the difference was found to be highly significant after 10 days. This means that the diffusion of hydroxyl ions of freshly mixed $\mathrm{Ca}(\mathrm{OH})_{2}$ is more than that of oily Metapex, and this result is consistent with Larsen and Horsted-Bindslev. ${ }^{[28]}$ It was also observed that oil paste containing $\mathrm{Ca}(\mathrm{OH})_{2}$ was having low solubility and were mainly deficient in both ion release and antimicrobial properties. The aqueous suspension showed the highest $\mathrm{pH}$ and calcium ion liberation.

After 14 days, Metapex group $\mathrm{pH}$ was higher than freshly mixed $\mathrm{Ca}(\mathrm{OH})_{2}$ but was not statistically significant. This could be due to Metapex comprising of $\mathrm{Ca}(\mathrm{OH})_{2}$ and iodoform mixture in silicon oil. The low solubility and diffusibility could preserve the high $\mathrm{pH}$ till 14 days. The $\mathrm{pH}$ of both $\mathrm{Ca}(\mathrm{OH})_{2}$ preparations reached nearly the same after 30 days.

\section{CONCLUSION}

The freshly mixed $\mathrm{Ca}(\mathrm{OH})_{2}$ showed the higher $\mathrm{pH}$ after 7 and 10 days than that of the Metapex. Significant statistical difference was observed after 10 days. For Metapex group, $\mathrm{pH}$ was higher than freshly mixed
$\mathrm{Ca}(\mathrm{OH})_{2}$ after 14 days. However, it was not statistically significant. After 30 days, Metapex group attained the same $\mathrm{pH}$ as that of the $\mathrm{Ca}(\mathrm{OH})_{2}$. Thus, $\mathrm{Ca}(\mathrm{OH})_{2}$ preparations showed higher $\mathrm{pH}$ after $7,10,14$, and 30 days, while the Metapex in our study continued to have higher $\mathrm{pH}$ after 14 days but achieved nearly the same $\mathrm{pH}$ after 30 days as that of the $\mathrm{Ca}(\mathrm{OH}) 2$.

\section{Financial support and sponsorship}

Nil.

\section{Conflicts of interest}

There are no conflicts of interest.

\section{REFERENCES}

1. Endo MS, Ferraz CC, Zaia AA, Almeida JF, Gomes BP. Quantitative and qualitative analysis of microorganisms in root-filled teeth with persistent infection: Monitoring of the endodontic retreatment. Eur J Dent 2013;7:302-9.

2. Bystrom A, Claesson R, Sundqvist G. The antibacterial effect of camphorated paramonochlorophenol, camphorated phenol and calcium hydroxide in the treatment of infected root canals. Endod Dent Traumatol 1985;1:170-5.

3. Mohammadi Z, Shalavi S, Yazdizadeh M. Antimicrobial activity of calcium hydroxide in endodontics: A review. Chonnam Med J 2012;48:133-40.

4. Teoh YY, Athanassiadis B, Walsh LJ. Comparison of commercial calcium hydroxide pastes for prolonged antibacterial effect using a colourimetric assessment. Materials (Basel) 2018;11. pii: E348.

5. Mustafa M, Saujanya KP, Jain D, Sajjanshetty S, Arun A, Uppin L, et al. Role of calcium hydroxide in endodontics: A review. Glob J Med Public Health 2012;1:66-70.

6. Poggio C, Beltrami R, Colombo M, Ceci M, Dagna A, Chiesa M, et al. In vitro antibacterial activity of different pulp capping materials. J Clin Exp Dent 2015;7:e584-8.

7. Sireesha A, Jayasree R, Vidhya S, Mahalaxmi S, Sujatha V, Kumar TS, et al. Comparative evaluation of micron-and nano-sized intracanal medicaments on penetration and fracture resistance of root dentin - An in vitro study. Int J Biol Macromol 2017;104:1866-73.

8. Ndiaye D, Diongue K, Bane K, Seck A, Niang SO, Lèye Benoist F, et al. Efficacy of sodium hydroxide at $2.5 \%$, chlorhexidine gluconate at $0.5 \%$ and calcium hydroxide against Candida albicans. J Mycol Med 2016;26:317-22

9. de Souza CA, Teles RP, Souto R, Chaves MA, Colombo AP. Endodontic therapy associated with calcium hydroxide as an intracanal dressing: Microbiologic evaluation by the checkerboard DNA-DNA hybridization technique. J Endod 2005;31:79-83.

10. Trope M, Moshonov J, Nissan R, Buxt P, Yesilsoy C. Short vs. long-term calcium hydroxide treatment of established inflammatory root resorption in replanted dog teeth. Endod Dent Traumatol 1995;11:124-8.

11. Kazemipoor M, Tabrizizadeh M, Dastani M, Hakimian R. The effect of retreatment procedure on the $\mathrm{pH}$ changes at the surface of root 


\section{Mustafa, et al.: Diffusion of calcium hydroxide through dentinal tubules of retreated root canals}

dentin using two different calcium hydroxide pastes. J Conserv Dent 2012;15:346-50.

12. Pashley DH, Livingston MJ. Effect of molecular size on permeability coefficients in human dentine. Arch Oral Biol 1978;23:391-5.

13. Saber SE, El-Hady SA. Development of an intracanal mature Enterococcus faecalis biofilm and its susceptibility to some antimicrobial intra-canal medications: An in vitro study. Eur J Dent 2012;6:43-50.

14. Cai M, Abbott P, Castro Salgado J. Hydroxyl ion diffusion through radicular dentine when calcium hydroxide is used under different conditions. Materials (Basel) 2018;11. pii: E152

15. Ba-Hattab R, Al-Jamie M, Aldreib H, Alessa L, Alonazi M. Calcium hydroxide in endodontics: An overview. Open J Stomatol 2016;6:274-89.

16. Siqueira JF Jr., Fraga RC, Garcia PF. Evaluation of sealing ability, pH and flow rate of three calcium hydroxide-based sealers. Endod Dent Traumatol 1995;11:225-8.

17. Kontakiotis EG, Tzanetakis GN, Loizides AL. A comparative study of contact angles of four different root canal sealers. J Endod 2007;33:299-302.

18. Madarati AA, Zafar MS, Sammani AMN, Mandorah AO, Bani-Younes HA. Preference and usage of intracanal medications during endodontic treatment. Saudi Med J 2017;38:755-63.

19. Rizvi A, Zafar MA, Farid WM, Gazal G. Assessment of antimicrobial efficacy of MTAD, sodium hypochlorite, EDTA and chlorhexidine for endodontic applications: An in vitro study. Middle East J Sci Res 2014;21:353-7.

20. Yücel AC, Aksoy A, Ertaş E, Güvenç D. The pH changes of calcium hydroxide mixed with six different vehicles. Oral Surg Oral Med Oral
Pathol Oral Radiol Endod 2007;103:712-7.

21. Dausage P, Dhirawani RB, Marya J, Dhirawani V, Kumar V. A comparative study of ion diffusion from calcium hydroxide with various herbal pastes through dentin. Int J Clin Pediatr Dent 2017;10:41-4.

22. Gomes BP, Souza SF, Ferraz CC, Teixeira FB, Zaia AA, Valdrighi L, et al. Effectiveness of $2 \%$ chlorhexidine gel and calcium hydroxide against Enterococcus faecalis in bovine root dentine in vitro. Int Endod J 2003;36:267-75.

23. Komabayashi T, D’souza RN, Dechow PC, Safavi KE, Spångberg LS. Particle size and shape of calcium hydroxide. J Endod 2009;35:284-7.

24. Eftekhar B, Moghimipour E, Eini E, Jafarzadeh M, Behrooz N. Evaluation of hydroxyl ion diffusion in dentin and injectable forms and a simple powder-water calcium hydroxide paste: An in vitro study Jundishapur J Nat Pharm Prod 2014;9:e14029.

25. Sáez MDM, López GL, Atlas D, de la Casa ML. Evaluation of pH and calcium ion diffusion from calcium hydroxide pastes and MTA. Acta Odontol Latinoam 2017;30:26-32.

26. Lage Marques JL, Conti R, Antoniazzi JH, Guth I. In vitro assessment of the ionic dissociation velocity of calcium hydroxide to different vehicles. Rev Odontol Univ São Paulo 1994;8:81-7.

27. Komabayashi T, Ahn C, Spears R, Zhu Q. Comparison of particle morphology between commercial- and research-grade calcium hydroxide in endodontics. J Oral Sci 2014;56:195-9.

28. Larsen MJ, Horsted-Bindslev P. A laboratory study evaluating the release of hydroxyl ions from various calcium hydroxide products in narrow canal-like tubes. Int Endod J 2000;33:238. 